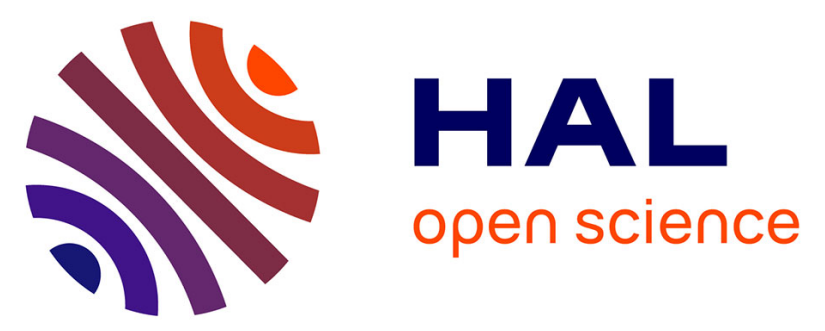

\title{
High-protein diets for weight management: Interactions with the intestinal microbiota and consequences for gut health. A position paper by the my new gut study group
}

Francois F. Blachier, Martin Beaumont, Kevin Joseph Portune, Nils Steuer, Annaig Lan, Marc Audebert, Nadezda N. Khodorova, Mireille M. Andriamihaja, Gheorghe Airinei, Robert Benamouzig, et al.

\section{To cite this version:}

Francois F. Blachier, Martin Beaumont, Kevin Joseph Portune, Nils Steuer, Annaig Lan, et al.. Highprotein diets for weight management: Interactions with the intestinal microbiota and consequences for gut health. A position paper by the my new gut study group. Clinical Nutrition, 2019, 38 (3), pp.1012-1022. 10.1016/j.clnu.2018.09.016 . hal-02618730

\section{HAL Id: hal-02618730 \\ https://hal.inrae.fr/hal-02618730}

Submitted on 22 Oct 2021

HAL is a multi-disciplinary open access archive for the deposit and dissemination of scientific research documents, whether they are published or not. The documents may come from teaching and research institutions in France or abroad, or from public or private research centers.
L'archive ouverte pluridisciplinaire HAL, est destinée au dépôt et à la diffusion de documents scientifiques de niveau recherche, publiés ou non, émanant des établissements d'enseignement et de recherche français ou étrangers, des laboratoires publics ou privés.

\section{(ㄷ)(1) $\$$}

Distributed under a Creative Commons Attribution - NonCommerciall 4.0 International 
1 High-protein diets for weight management: Interactions with the intestinal 2 microbiota and consequences for gut health. A position paper by the My New

3 Gut study group

4

5 François Blachier ${ }^{a^{*}}$, Martin Beaumont ${ }^{\mathrm{a}}$, Kevin Joseph Portune ${ }^{\mathrm{b}}$, Nils Steuer ${ }^{\mathrm{c}}$, Annaïg Lan ${ }^{\mathrm{a}}$, Marc

6 Audebert $^{\mathrm{d}}$, Nadezda Khodorova ${ }^{\mathrm{a}}$, Mireille Andriamihaja ${ }^{\mathrm{a}}$, Gheorghe Airinei ${ }^{\mathrm{c}}$, Robert Benamouzig ${ }^{\mathrm{c}}$,

7

8

9

\section{Summary}

\section{(} (1)

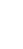

Anne-Marie Davila ${ }^{\mathrm{a}}$, Lucie Armand ${ }^{\mathrm{a}}$, Simone Rampelli ${ }^{\mathrm{e}}$, Patrizia Brigidi ${ }^{\mathrm{e}}$, Daniel Toméa ${ }^{\mathrm{a}}$, Sandrine

Paule Claus ${ }^{\mathrm{f}}$, Yolanda Sanz

${ }^{a}$ UMR PNCA, AgroParisTech, INRA, Université Paris-Saclay, Paris, France

${ }^{b}$ Microbial Ecology, Nutrition and Health Research Unit, Institute of Agronomy and Food Technology, Spanish National Research Council, Valencia, Spain

${ }^{c}$ Department of Gastroenterology, Avicenne Hospital, Assistance Publique-Hôpitaux de Paris, Bobigny, France

${ }^{d}$ Toxalim, Research Centre in Food Toxicology, INRA, Toulouse, France

${ }^{e}$ Department of Pharmacy and Biotechnology, University of Bologna, Bologna, Italy

${ }^{f}$ Department of Food Nutritional Sciences, University of Reading, Reading, United Kingdom

*Corresponding author. UMR PNCA, 16 rue Claude Bernard, 75005 Paris, France.

E-mail address: francois.blachier@agroparistech.fr 4 

2

Background and aim: This review examines to what extent high-protein diets (HPD), which may favor body weight loss and improve metabolic outcomes in overweight and obese individuals, may also impact the gut environment, shaping the microbiota and the host-microbe (co)metabolic pathways and products, possibly affecting large intestine mucosa homeostasis.

Methods: PubMed-referenced publications were analyzed with an emphasis on dietary intervention studies involving human volunteers in order to clarify the beneficial vs. deleterious effects of HPD in terms of both metabolic and gut-related health parameters; taking into account the interactions with the gut microbiota.

Results: HPD generally decrease body weight and improve blood metabolic parameters, but also modify the fecal and urinary contents in various bacterial metabolites and co-metabolites. The effects of HPD on the intestinal microbiota composition appear rather heterogeneous depending on the type of dietary intervention. Recently, HPD consumption was shown to modify the expression of genes playing key roles in homeostatic processes in the rectal mucosa, without evidence of intestinal inflammation. Importantly, the effects of HPD on the gut were dependent on the protein source (i.e. from plant or animal sources), a result which should be considered for further investigations.

Conclusion: Although HPD appear to be efficient for weight loss, the effects of HPD on microbiotaderived metabolites and gene expression in the gut raise new questions on the impact of HPD on the large intestine mucosa homeostasis leading the authors to recommend some caution regarding the utilization of HPD, notably in a recurrent and/or long-term ways.

Keywords: High-protein diet, microbiota, bacterial metabolites and co-metabolites, large intestine mucosa

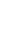
9 50 51 
In a context of a high proportion of overweight and obese individuals, notably in populations from Europe and the USA (1), numerous different types of weight-loss diets are currently proposed and consumed (2). Among them, high-protein diets (HPD), which represent a heterogeneous group of diets with different composition (3), are all characterized by a higher proportion of protein $(25-30 \%$ of total energy intake) among the two other dietary macronutrients (i.e. carbohydrates and fat) when compared with the usual macronutrient proportion. These HPD are used by millions of individuals around the world for weight-loss (4). One of the main rationales for the consumption of HPD is that it is generally recognized that, on a basis of equal energy content, protein is more satiating than carbohydrates and fats (5). Considering that weight gain is primarily observed when energy recovered from food is superior to energy expenditure, notably in relationship with physical exercise (6), HPD, by reducing dietary energy intake, is likely to help, at least transiently, in the process of body weight reduction (7).

However, there is presently no definition of the maximal amount of dietary protein that can be consumed without short- and/or long-term metabolic and physiopathological side effects. Indeed, if the benefits of decreased body weight in overweight and obese individuals in terms of metabolic and general health outcomes appear obvious based on numerous studies (8), then the interest of HPD consumption for such outcomes must be confronted with possible undesirable effects upon different tissues and organs in a beneficial over deleterious ratio perspective. For instance, it is well known that HPD are contraindicated in individuals with chronic kidney diseases or at risk for such diseases, as HPD may accelerate kidney dysfunctions $(9,10)$. Regarding the impact of HPD on gut health, this remains an emerging but important topic.

The aim of the present review is to present the available evidence, including recent data obtained in the MyNewGut European research project, in order to balance the advantages of HPD for weight loss and metabolic health against the potential risks of such unbalanced diets focusing on the gut ecosystem homeostasis. As a matter of fact, there are indications from clinical and experimental studies that dietary changes may modify the large intestine luminal environment with a potential impact on the colonic mucosa (11). 
PubMed-referenced publications were analyzed using the following terms in combination: [highprotein diet OR dietary protein OR protein source] / [intestinal microbiota OR bacterial metabolites OR co-metabolites] / [large intestine OR colon OR rectum] / [weight-loss OR overweight OR obesity]. Among the numerous papers found, priority was given for references related to dietary intervention studies with human volunteers, notably those reporting consequences in terms of intestinal physiology and physiopathology.

This review is part of a series of position paper of the MyNewGut project aiming at providing recommendations for dietary guidelines based on project results and the latest advantages in the field regarding insights gained in the role of the gut microbiome, as described in the introductory paper (12).

\section{High-protein diet, weight loss, and metabolic effects}

\subsection{High-protein diet and weight loss}

HPD can be defined in regards to the absolute amount of dietary protein (in grams) consumed per day, or to the proportion of dietary protein in the total energy intake; or to the amount of dietary protein per unit of body weight. A useful reference can be found on the recommended daily amount of dietary protein which has been determined to be equal to $0.83 \mathrm{~g}$ of protein per $\mathrm{kg}$ body weight per day ,(13) thus representing $58.1 \mathrm{~g}$ dietary protein per day for an individual weighting $70 \mathrm{~kg}$. As a matter of fact, mean dietary protein consumption is largely above these recommended value for instance in France since it averages $87.3 \mathrm{~g} /$ day (average value for men and women) (14), and in the USA where it averages $82.8 \mathrm{~g} /$ day taking into account men and women dietary protein consumption (15), thus representing approximately 1.5 fold the recommended daily amount of protein. HPD can represent as much as 5 fold higher than the recommended daily amount (4), but it is generally considered that diets containing at least $25-30 \%$ of energy in the form of protein are HPD (16). As a matter of comparison, in France, $16.8 \%$ of the dietary energy comes from protein in typical diets (14). Incidentally, HPD are also largely consumed by athletes who wish to increase their muscle mass and performance, but this 
aspect is out of the scope of the present review and will not be described here, although the readers are referred to excellent reviews on that topic $(17,18)$.

Two main types of controlled clinical intervention studies with HPD have been performed. The first one is the "ad libitum" studies in which volunteers consume the amount of HPD or control normoproteic diet (NPD) until they naturally stop their food consumption. In these studies, due to the satiating effects of HPD, volunteers on HPD generally eat less food than the control NPD subjects, and consequently significantly decrease their body weight compared to the body weight measured at the onset of the dietary intervention. In the study of Weigle et al. (19), HPD given ad libitum for 2 weeks resulted in a decrease of body weight. Johnstone et al. (20) also reported reduction of food intake and body weight following 4-week-consumption of HPD. Ad libitum consumption of HPD for 6 months resulted in a marked decrease of body fat when compared with individuals receiving a NPD (21). In a study on weight loss maintenance after dietary energy restriction, it has been shown that HPD, when given for 12 weeks (22) or 12 months (23), is efficient for weight control. However, in the "real life" condition, a vast majority of individuals, after initial body weight reduction, recover their initial body weight in the long term (24), leading possibly to recurrent episodes of weight-loss HPD consumption. A study using ad libitum HPD has shown that meat-based HPD is not more efficient for body weight decrease than protein from plant origin (25).

The second type of HPD intervention studies consists of increasing the proportion of protein in the diet exercise, is a major parameter for fixing the evolution of body weight for one given individual. compared to the control, but in that case, the amount of energy consumed between groups is maintained constant. This is generally done by decreasing the relative proportion of another macronutrient in the diet, namely carbohydrates or fats. In that kind of isocaloric clinical protocol, the studies generally found no or little effect of such diets for body weight reduction $(16,26)$ corresponding to the view that the amount of dietary energy intake, at a constant level of physical

A third type of studies related to the use of HPD in obese patients are those related to the use of such diet for maintaining the lean mass in malnourished obese patients. Since we will not develop this aspect in our review, the readers are referred to a recent review paper on that topic (27). 


\subsection{High-protein diet and metabolic parameters}

138 The interpretation of the effect of HPD on metabolic parameters can be somewhat complicated. For

139 instance, if a HPD is given to overweight individuals in an "ad libitum" protocol, it will be difficult to

140 determine what part the increased proportion of protein in the diet plays in the normalization of

141 metabolic parameters in comparison with the part played by the decrease of energy intake due to the

142 satiating effect of HPD and the resultant decrease of body weight. In overweight and obese

143 individuals, marked decrease of body weight, whatever the cause, allows the normalization of

144 metabolic parameters $(8,28)$.

145 In protocols in which the experimental diets are isocaloric, the HPD, as said above, are necessarily

146 decreased in another macronutrient, thus rendering it difficult to attribute the effects of HPD solely to

147 the increased content of protein and/or to the reduced amount of the other macronutrient. In a recent

148 randomized, parallel, double-blind controlled study in which the HPD (using milk casein or soy

149 protein as supplements) were given to volunteers for 3 weeks, no significant changes on any of the

150 biochemical and anthropometric parameters were measured in blood in fasting conditions when

151 compared with control subjects receiving a normoproteic isocaloric diet. A notable exception to this

152 lack of change in parameters was observed for systolic blood pressure, which was decreased in the

153 group of volunteers receiving the soy protein supplementation; an effect that was likely due to the

154 presence of protein-associated isoflavones in the protein extract (26). Thus, under condition of equal

155 energy consumption, HPD appear to exert no short-term sizeable effect on the metabolic and

156 anthropometric parameters.

\section{High-protein diet and changes in the gut ecosystem}

159 The process of protein digestion in the small intestine is a very efficient process with digestibility usually ranging from 89 to $95 \%$, depending on the nature of the protein $(29,30)$. Generally speaking, proteins from animal sources are overall more digestible than proteins from plant sources (31). Some sources of protein, for instance rapeseed protein, are known for their lower digestibility (32). In

163 addition, food cooking $(33,34)$ and food matrix structure (35) can impact protein digestibility. 164 Importantly, and as a result of incomplete digestion in the small intestine, a residual amount of 
undigested protein and peptides, together with individual amino acids are transferred through the ileocaecal junction in the large intestine (36). Based on a regular western diet, it has been determined that approximately $12 \mathrm{~g}$ of protein and peptide from both dietary and endogenous origin escape digestion in the small intestine, thus reaching the colonic lumen (37). This amount of nitrogenous material is increased nearly proportionally when the amount of dietary protein increases (29). From studies evaluating the proportion of dietary and endogenous protein which escape digestion and move from the ileum to the large intestine, it has been determined that the majority of the ileal nitrogen is originating from endogenous losses (1-2 g/day), while the nitrogen from dietary origin represents 0.7 $1.2 \mathrm{~g} /$ day (36). The results obtained in animal models suggest that the part ascribed to endogenous protein is not vastly different according to the amount of protein consumed (38). Since the large intestine luminal content is characterized by a much more abundant microbiota than what is measured in the small intestine (39), and also by a much slower transit time (40), the proteins and peptides which enter the large intestinal luminal content undergo the catalytic action of bacterial proteases and peptidases which release sequentially shorter peptides and amino acids (41). The large intestinal epithelium, in contrast with the small intestinal epithelium which is very efficient for oligopeptide and amino acid absorption, is not believed to transfer any significant amount of amino acids from the lumen to the bloodstream, except in the neonatal period $(42,43)$. Therefore, protein and peptidederived amino acids are metabolized by the large intestinal microbiota which use them for protein synthesis and catabolic pathways with the production of numerous intermediates and final metabolites (44); a net amount of these latter being able to accumulate within the luminal content (Figure 1). This process of protein degradation is more active in the distal part than in the proximal part of the large intestine (45). In the case of HPD consumption, the increased transfer of nitrogenous compounds in the large intestine is liable to modify the microbiota composition, and/or to change the microbiota diversity, and/or its metabolic activity, and finally to change the production of bacterial metabolites with possible consequences for the large intestinal mucosa metabolism, physiology and health (46-50) as described below.

\subsection{High-protein diets and intestinal microbiota composition}


Relatively few human intervention studies have examined the short-term (less than 4 weeks) effects of

HPD on the gut microbiota composition (Table 1). Two main factors preclude direct comparison between the studies presented in Table 1: (i) differences in energy intake (e.g. calorie restriction) and (ii) differences in fiber intake. These two parameters are known to have a profound influence on the gut microbiota composition and should therefore be considered as important potential confounding factors with the effects of dietary protein intake. Moreover, there are large variations between the studies in terms of methods used to analyze the composition of the gut microbiota. With these limitations in mind, it is still possible to propose some general conclusion regarding the effects of dietary protein intake on the gut microbiota.

Two of the studies in Table 1 used HPD without modification of dietary fiber and energy intake. (26, 45). Using $16 \mathrm{~S}$ rDNA sequencing for fecal or rectal biopsy samples, and denaturing gradient gel electrophoresis (DGGE) for fecal samples, respectively, these two studies did not detect changes in the gut microbiota composition after the HPD (Table 1). In a study by David et al. (51) a diet containing dietary protein from animal origin containing almost no fibers was given ad libitum for 5 days. This dietary intervention resulted in almost doubling the protein intake (i.e. $30.1 \%$ of energy intake) as compared to the protein consumption at the onset of intervention, and was found to impact the microbiota composition by increasing the abundance of bile-tolerant microorganisms (Alistipes, Bilophila, and Bacteroides), and by decreasing the levels of Firmicutes that metabolize plant polysaccharides (Roseburia, Eubacterium rectale, and Ruminococcus). Such a HPD was found to change the microbiota $\beta$-diversity within 2 days. However, this latter effect appeared to be transient, as the $\beta$-diversity returned to the initial configuration within 2 days after the end of the intervention (51). However, these changes could not be attributed solely to the level of protein intake since there was considerable concomitant modification of fat intake (in addition to fiber intake) in this study.

The other studies presented in Table 1 used HPD with caloric restriction that resulted in weight-loss. Two of them (different analysis of the same samples), showed that the HPD induced an alteration of the gut microbiota composition with a decreased abundance of presumed beneficial bacteria such as Bifidobacterium or Rosburia/Eubacterium rectale (52, 53) However, both resistant starch and total 
carbohydrates were also lower in the high-protein/weight loss diet compared to the maintenance diet (52). This is an important point to consider as resistant starch has been positively associated with the abundance of Bifidobacterium and Eubacterium spp $(54,55)$; and a reduction in carbohydrates led to decreases in both genera (56). In another study, a weight-loss HPD combined with an increase in fiber intake also induced a decrease in Eubacterium rectale but increased bacterial gene richness in individuals with low gene counts together with an increase abundance of bacteria considered protective such as Faecalibacterium prausnitzii and Roseburi (57). Lastly, two other studies using weight-loss HPD combined with a low fiber intake observed a decrease in the total bacterial biomass and in the abundance of Bifidobacterium and Rosburia/Eubacterium rectale $(56,58)$.

Overall, the studies presented in Table 1 show that HPD have a limited effect on the gut microbiota composition when they are not associated with calorie restriction or with a modification of fiber intake. This conclusion may also be connected to the observed relatively little changes in the microbiota composition according to the diet when compared with the inter-individual variations (< $10 \%)(53)$.

\subsection{High-protein diets and impact on gut mucosa: potential role of bacterial metabolites}

The mixture of bacterial metabolites in the intestinal content is complex (59) and far from being fully characterized. Among these compounds, numerous metabolites are produced by the intestinal microbiota from amino acid substrates (60). The concentrations of these metabolites are usually measured in the feces, which are related to the concentrations of the luminal content within the most distal part of the large intestine, namely in the rectum. These metabolite concentrations depend on the bacterial production from the available substrates, on the bacterial composition and overall metabolic activity, on the absorption through the large intestinal epithelium, and on the transit time (61). (Figure 1). Other parameters may influence the concentrations of the different forms of the bacterial metabolites within the large intestine content. For instance, the luminal $\mathrm{pH}$, which will result from the overall acid/base balance in this compartment, will in turn determine the ratio of the different nonionized and ionized forms of ionic bacterial metabolites (62), which will affect their uptake from the luminal content to the colonocyte intracellular content. In addition, the situation is complicated by the 
fact that some bacterial metabolites (for instance hydrogen sulfide) can bind to fecal components, thus reducing the concentration of free (unbound) metabolites presumed to act on the epithelial cells (Figure 2) (63). We present below the effects of HPD on bacterial metabolites and their main effects observed in Humans and experimental animal models but the reader is referred to another recent review for more exhaustive description of the metabolites produced by the microbiota from amino acids (41).

3.2.1 Effects of high-protein diets on the fecal composition and effects of individual bacterial metabolites on colonic epithelial cells

Several intervention studies in humans have shown that HPD with different sources of dietary protein induce a shift from carbohydrate to protein degradation by the gut microbiota $(26,58,59,64)$, with an alteration of numerous bacterial metabolite concentrations in feces, thus indicating changes in the luminal environment of the colonic epithelial cells. In contrast with the high variability described above between human intervention studies regarding the effects of HPD on microbiota composition (Table 1), the effects of HPD on bacterial metabolites are more homogeneous despite differences in experimental design (Table 2). This observation emphasizes the importance of substrate availability, namely amino acids in our case, rather than taxonomic composition of the microbiota for determining the metabolic output in the large intestine. This could also be due to redundancy of functions and metabolic pathways in the microbiome, the collective genome of the microbiota (65).

Most of the studies in Table 2 reported that HPD consumption induced an increase in amino acidderived short-chain fatty acids (SCFA) such as isobutyrate, isovalerate, and 2-methylbutyrate (26, 49, 58). In contrast, a decrease in the SCFA butyrate was consistently found after HPD consumption (26, $51,56,58)$ albeit several of these studies included decreases in fiber content among the HPD. However, in a recent study by Beaumont et al. (26) volunteers from the HPD and control groups consumed a similar amount of dietary fibers and energy than the NPD group thus suggesting that the reduction of fecal butyrate concentration in HPD can be attributed primarily to the amount of protein in the diet. As butyrate is well-known as a major oxidative substrate and a regulator of histone 
acetylation, and thus of gene transcription in human colonocytes $(66,67)$, the measured decrease in its

277 fecal concentration after HPD is presumably detrimental for the rectal mucosa homeostasis.

278 Two studies in volunteers receiving a HPD found a marked increase in fecal ammonia concentrations

$279(59,64)$, while two others did not $(26,58)$, likely due to the different experimental protocols. Also, HPD were found to increase the concentrations of several S-containing metabolites $(59,68)$. For most of these metabolites, there is surprisingly no indication on the impact of such changes on the colonic/rectal epithelium renewal and functions. However, from in vitro studies with human or rodent colonocytes, there are indications that several amino acid-derived bacterial metabolites including hydrogen sulfide $\left(\mathrm{H}_{2} \mathrm{~S}\right)$, ammonia and $p$-cresol act as metabolic troublemakers towards colonocyte mitochondrial energy metabolism within the range of concentrations that are measured in the colonic content or in feces $(69,70)$.

In contrast, some bacterial metabolites derived from amino acids were found to exert beneficial effects on the intestinal epithelial barrier (reviewed in 11). For instance, indole which is produced from Ltryptophan has been shown to increase epithelial cell tight-junction resistance as will been detailed in the part 3.3. Another bacterial metabolites derived from tryptophan, namely indole propionic acid, has been shown recently to be efficient for decreasing the intestinal permeability in rodents (71). Thus, in order to document the beneficial versus deleterious effects of the mixture of bacterial metabolites contained within the intestinal content, it is clearly necessary to take into account the fact that these contents contain compounds with both positive and negative effects on the intestinal mucosa.

\subsubsection{Genotoxic and cytotoxic potential of fecal water recovered after high-protein diet consumption}

In order to get information on the possible overall cytotoxic and genotoxic potential of fecal watersoluble components after controlled dietary intervention, it is feasible to prepare the so-called "fecal water" samples by diluting and homogenizing fecal samples in aqueous medium, and test the supernatant on human colonocytes. Although fecal water samples do not contain all the luminal compounds and dilute the bacterial metabolites, fecal water toxicity has been proposed to represent a potential biomarker for intestinal disease risk (72). When an isocaloric HPD was given for 2 weeks to healthy human subjects in a crossover design, the mixture of water-soluble components recovered 
from the feces shown no increased genotoxicity or cytotoxicity potential towards human colonocytes when compared to the NPD (45). Similarly, in a study by Benassi-Evans et al. (73), the authors performed a nutritional intervention with HPD during 52 weeks using a parallel design with overweight and obese volunteers. They found that the fecal water recovered from individuals consuming HPD was not more genotoxic than ones recovered from control volunteers consuming isocaloric NPD. In accordance with the results presented above, in a study by Beaumont et al. (26), supplementation of the diet with either casein or soy protein for 3 weeks, did not result in higher cytotoxic potential of the fecal water when compared with the results obtained from isocaloric NPD volunteers. Thus, collectively, the available data indicate that the fecal water samples recovered from volunteers consuming HPD in short- and medium terms show no increased genotoxic and cytotoxic potential in vitro towards colonic epithelial cells than samples recovered from control NPD.

\subsection{High-protein diet and urinary metabolome}

Urinary metabolomic analysis is useful in order to identify the bacterial metabolites and cometabolites (produced by the microbiota and metabolized by the host) which have been produced by the gut microbiota, absorbed from the lumen to the bloodstream through the intestinal epithelium (with or without metabolism in colonocytes), possibly further metabolized by the host in the liver or other organs outside the splanchnic area, and finally excreted in the urine where they accumulate (Figure 3). For instance, HPD ingestion results in the increased urinary excretion of the bacterial metabolite phenol (64). This is of interest as phenol has been shown to act as a cytotoxic compound towards colonocytes (74); and as impaired phenol detoxification has been associated with ulcerative colitis (75).

In addition, the cometabolite $p$-cresyl sulfate is produced in the colon mucosa and the liver from the bacterial metabolite $p$-cresol, which itself is produced by the microbiota from the amino acid Ltyrosine (76). Urinary concentration of $p$-cresyl sulfate has been repetitively found to be increased after HPD consumption $(26,59,77)$ when compared with control NPD (Table 2). Since $p$-cresol has been shown to inhibit colonocyte oxygen consumption, and to be genotoxic towards colonocytes (70), 
detoxifying metabolic pathway for this bacterial metabolite. This possibility has been challenged by the fact that $p$-cresyl sulfate displayed pro-inflammatory and cytotoxic effects on renal tubular epithelial cells $(78,79)$, and that serum $p$-cresyl sulfate level may help in predicting progression of chronic kidney disease $(80,81)$.

In a study by Beaumont et al. (26), the relative concentration of another urinary cometabolite, namely indoxyl sulfate, increased after HPD (Table 2). Since indole, the precursor for the synthesis of indoxyl sulfate in the liver, has been shown to contribute to the maintenance of the colonic barrier function $(82,83)$ and to alleviate hepatic inflammation $(84)$, this bacterial metabolite can be considered as beneficial for the host. However, in order to establish the beneficial vs. deleterious effects of indole on the colon epithelium, it is important to consider that this bacterial metabolite activates the aryl hydrocarbon receptor (AhR)-mediated transcription of Cyp 1a1 and Cyp 1b1 in human colonocytes $(85,86)$. These two enzymes belongs to the cytochrome P450 family which, apart from their role in the deactivation of deleterious compounds and xenobiotics, can catalyse the bioactivation of procarcinogen compounds into carcinogens (87-89). In addition, indoxyl sulfate is suspected to act as a uremic toxin contributing to renal disease progression (90-92).

Thus, the analysis of the urinary metabolome gives important information regarding the exposure of the intestinal mucosa to bacterial metabolites (Figure 3), even if the results obtained emphasizes the difficulty to predict how changes of a complex mixture of bacterial metabolites will impact the colonic/rectal mucosa according to the time of exposition and respective concentrations.

\subsection{High-protein diets and gut mucosa inflammation}

Although the results of epidemiological studies regarding the association between HPD consumption and risk of inflammatory bowel diseases (IBD) are heterogeneous (93), two studies have shown that a high amount of animal protein intake is associated with increased inflammatory bowel disease incidence and relapse $(94,95)$. However, short-term supplementation (3 weeks) with casein or soy protein, did not show any sign of rectal mucosal inflammation based on the measurement of pro- 
inflammatory cytokines in rectal biopsies, and on the fecal concentrations of calprotectin and secreted IgA, when compared with an isocaloric NPD (26).

Participation of some bacterial metabolites on the process of mucosal inflammation in pre-disposed subjects may be related to a reduced capacity of the mucosa for deleterious metabolite detoxification. For instance, it has been reported that impaired $\mathrm{H}_{2} \mathrm{~S}$ detoxification in intestinal mucosa is associated with Crohn's disease (96) and ulcerative colitis (97). These results are important to be taken into account, knowing that increased protein consumption is correlated with increased $\mathrm{H}_{2} \mathrm{~S}$ fecal excretion in volunteers (68), and that excessive luminal $\mathrm{H}_{2} \mathrm{~S}$ decreases colonocyte respiration and increases the expression of several genes involved in IBD in a rodent model (98). It can therefore be predicted that there might be differences between individuals in terms of mucosal response to HPD according to individual detoxification capacities.

\subsection{High-protein diets and gene expression in gut mucosa}

The first experimental evidence using transcriptomic analysis which has shown that casein-containing HPD can modify gene expression in the colonic mucosa were obtained in the rat model by Mu et al. (99) using a 6-week- dietary intervention protocol with isocaloric experimental (HPD) and control (NPD) diets. Beaumont et al. (100) used a 2 week-intervention protocol with whole milk proteincontaining HPD in the rat model to demonstrate that HPD down-regulates colonic epithelial cell gene

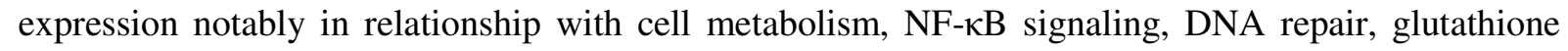
metabolism and cellular adhesion, when compared with gene expression in colonocytes recovered from isocaloric NPD. In this latter study, the HPD was found to up-regulate the expression of genes related to cell proliferation and chemical barrier function. These animal studies allow to establish the new proof of concept according to which increasing the amount of protein in the diet will result in a modification of gene expression in the colonic mucosa, and more specifically in the colonic epithelial cells. Further, a randomized controlled study with overweight volunteers reported that 3 week-dietary supplementation with either casein or soy protein resulted in small amplitude changes in the 
expression of numerous genes in the rectal mucosa, notably for genes involved in homeostatic processes such as cell cycle or cell death (26).

\subsection{The effects of high-protein diets on the fecal and urinary metabolome and on the large intestine} mucosa according to different protein sources

It can be hypothesized that the source of protein used in the HPD studies may represent an important parameter for modulating the colonic epithelium luminal environment and gene expression in the rectal mucosa. First, as presented above, different dietary proteins displayed different digestibility characteristics. Second, the differences in the amino acid composition between proteins provide the intestinal microbiota with different amounts of individual amino acids as substrates for the microbiota metabolic activity, thus potentially resulting in different fecal bacterial metabolite compositions and urinary bacterial/host cometabolites in the urine. Up to now, this hypothesis has been little explored but one recent study reported that when the habitual diet is supplemented with either milk casein or soy protein, differences are observed in the fecal and urinary metabolome, with such differences coinciding with changes in gene expression in the rectal mucosa (26). Indeed, in the case of supplementation with casein, when compared with the isocaloric NPD group, the feces were characterized by increased relative concentration of 2-methylbutyrate; while in the case of supplementation with soy protein, an increase of this bacterial metabolite was also measured but together with an increase of valerate, tyramine, and phenylacetate. Regarding the urinary metabolome, casein supplementation resulted in increased urea, isobutyrate, 3-hydroxybutyrate, 3hydroxyisovalerate, $p$-cresyl sulfate, phenylacetylglutamine and indoxylsulfate relative concentration; while supplementation with soy protein resulted in an increased of the same metabolites but not of the uremic toxin $p$-cresyl sulfate, the co-metabolite produced from $p$-cresol (79).

More importantly, casein and soy protein HPD were found to differentially modify the expression of genes playing key roles in the maintenance of the rectal mucosa homeostasis maintenance in general, and in colonic health (gastrointestinal diseases and cancer) in particular. At the cellular level, the casein diet was specifically associated with increased expression of genes related to extracellular matrix, cell adhesion, and mucus production; while the soy protein diet was specifically associated 
with modification of the expression of genes associated with oxidative stress and detoxification processes. Expression of other genes associated with cellular processes like apoptosis, cell cycle and proliferation, and cytoskeleton formation were modified by both casein and soy protein (26). To determine if such changes in gene expression impact the rectal epithelium renewal and functions, and/or if it corresponds to an adaptation towards a changing luminal environment, new experiments are required. Regarding this latter aspect, the fact that the expression of genes related to mucus production was solely increased in the rectal mucosa of volunteers after casein supplementation but not after soy protein supplementation, may indicate an adaptation of the rectal mucosa towards a more aggressive luminal environment following casein-based HPD consumption.

422

\section{Conclusion and perspectives}

Although it appears that HPD can help in diminishing the dietary intake, and thus favor weight loss, there are some results which raise new questions on the safety of their utilization. It must be recognized that, according to the available literature, there is no definitive evidence that such diets are deleterious for gut health in short- and medium- term intervention studies conducted so far. Indeed, as presented above, short-term consumption of HPD by itself neither increases the inflammation of the large intestinal mucosa, nor increases the in vitro genotoxicity and cytotoxicity of the mixture of compounds contained in the fecal water extracts in healthy subjects. However, HPD have been shown in a repetitive manner to decrease fecal butyrate concentrations. Since butyrate is generally considered as a fuel substrate and a regulator of gene expression in the rapidly renewing colonic epithelial cells, this decrease must be seen as potentially deleterious for the colonic mucosa homeostasis. The same remark can be made regarding the finding that HPD consumption results in increased exposition of the intestinal mucosa to $p$-cresol, a bacterial metabolite with genotoxic and metabolic troublemaker characteristics towards colonocytes (70). In addition, $p$-cresol is the precursor 437 of $p$-cresyl sulfate, a cometabolite with reported cytotoxic activity towards renal cells $(78,79)$ (Figure 438 3). Conversely, there is evidence that HPD increases the exposure of the large intestine mucosa to 439 indole, a bacterial metabolite considered as an important player in the maintenance of the epithelial barrier function. However, this positive effect of indole on the intestinal epithelium must be 
counterbalanced by the suspicion that indoxyl sulfate, a cometabolite of indole produced in the liver, is also acting as a uremic toxin $(90,101)$ (Figure 3). Then, the different effects of bacterial metabolites and cometabolites on different cell types, either within the intestinal mucosa as detailed in the present paper, or at the periphery, makes it difficult to predict if one given compound in a mixture should be considered as overall beneficial or deleterious. The finding that an increased consumption of dietary protein modifies within 3 weeks the normal expression of genes known to be involved in processes related to the maintenance of the rectal mucosal homeostasis (26), represents an important new finding which should be taken into consideration before formulating any recommendation on HPD consumption.

Regarding the effects of amino acid-derived bacterial metabolites on metabolic parameters, recent data suggest that some of these metabolites might contribute to an improvement of some of these parameters. For instance, indole has been shown in vitro to modulate the secretion of the incretin glucagon-like peptide 1 (GLP-1) (102). Moreover, hydrogen sulfide produced by the gut microbiota has been shown to lower blood pressure in rats (103), to improve glucose metabolism, and to increase GLP-1 secretion in mice (104). Lastly, several neurotransmitters can be produced by the gut microbiota from amino acids (41), and it can be speculated that this may contribute to the dietary protein- induced satiety. Further studies, notably with larger groups of human volunteers, and of longer duration are needed to determine whether the potential effects of amino acid-derived bacterial metabolites, depending on the protein sources, could participate in the beneficial metabolic effects of HPD associated with body weight reduction.

\section{Implications for dietary recommendation regarding high-protein diet consumption}

Although body weight reduction associated with ad libitum HPD consumption in overweight and obese individuals is obviously associated with favorable outcomes, the data obtained principally from clinical trials with human volunteers, dietary intervention in animal models, and in vitro experiments with human colonic epithelial cells have shown that HPD modifies the luminal environment of the rectal epithelium and impacts gene expression in the mucosa. We therefore recommend caution in the utilization of HPD diets for body weight loss, taking into account the possible regain of body weight 
after HPD consumption, which may lead to redundant and long-term utilization of HPD. Considering the most recent evidence showing that the effects of HPD on the gut depend on the protein source (i.e. from plant and animal sources), not only the quantity, but also the quality of dietary protein should be considered for further investigations and possibly for future dietary recommendations.

\section{Acknowledgement}

The MyNewGut project is financially supported by a grant from the EU $7^{\text {th }}$ Framework Programme under Grant Agreement 613979. The EU is not liable for the content presented in this publication.

\section{Conflict of interest}

FB, MB, KJP, NS, AL, MA, NK, MA, GA, RB, AMD, LA, SR, PB, DT, SPC, and YS declare no competing interest in relation to this paper.

\section{Legends of figures:}

Figure 1. Schematic view of the fate of undigested proteins in case of High-Protein Diet (HPD) consumption. HPD diet consumption increases the transfer of dietary proteins from the ileum to the large intestine. The proteases and peptidases of the microbiota release amino acids which can be incorporated in the bacterial proteins or lead to a multitude of metabolic end products, notably in the distal parts of the large intestine. Some of these metabolites are known to be transferred by the colonic epithelial cells from the luminal content to the portal bloodstream with or without prior metabolism in the colonocytes. The concentrations of bacterial metabolites in the lumen are the net result of production/utilization by the microbiota, and absorption through the colonic epithelium. The metabolites measured in the feces is a reflection of the metabolites present in the rectum.

Figure 2. Schematic view of the entry and metabolism of bacterial metabolites in the colonic epithelial cells. 
496 Several bacterial metabolites in the luminal content can enter colonocytes by processes of diffusion or

497 transport. Although some of them can be released as such in the bloodstream, several bacterial 498 metabolites are known to undergo intracellular metabolism leading to the production of co499 metabolites. Bacterial metabolites and co-metabolites can be released in the portal bloodstream and 500 reach the liver and peripheric organs outside the splanchnic area. Finally, these compounds can 501 accumulate in urine after glomerular filtration and/or tubular secretion by kidneys.

502 Figure 3. Schematic view of the impact of high-protein diet (HPD) consumption on the bacterial 503 metabolite and co-metabolite concentrations in feces and urine.

504 Undigested proteins and peptides enter the large intestine and are metabolized by the microbiota which 505 produce various metabolites from amino acids. Some of these metabolites are partly absorbed through 506 the large intestine epithelium, while the residual amount of metabolites are excreted in the feces. 507 Absorbed metabolites reach the liver where some of them undergo further metabolism. Cometabolites 508 and metabolites are finally excreted in the urine. HPD consumption results in measurable 509 modifications of the concentration of bacterial metabolites in feces and urine. As indicated in the text, 510 some compounds originating from the microbial metabolic activity (like butyrate and $\mathrm{H}_{2} \mathrm{~S}$ ) are known 511 to impact energy metabolism and gene expression in colonocytes, while some of them (like indole) are 512 implicated in the maintenance of the epithelial barrier function. Some co-metabolites measured in 513 urine (like indoxylsulfate and $p$-cresylsulfate) are suspected to act as uremic toxins. 
Table 1: Effects of high-protein diet on intestinal microbiota composition. The main characteristics and findings from human intervention studies using high-protein diets are summarized. BMI: body mass index, DGGE: denaturing gradient gel electrophoresis, FISH: fluorescence in situ hybridization, \% E: \% of energy intake, g/d: grams/day. For carbohydrates and fat intake, the readers are referred to the original publications.

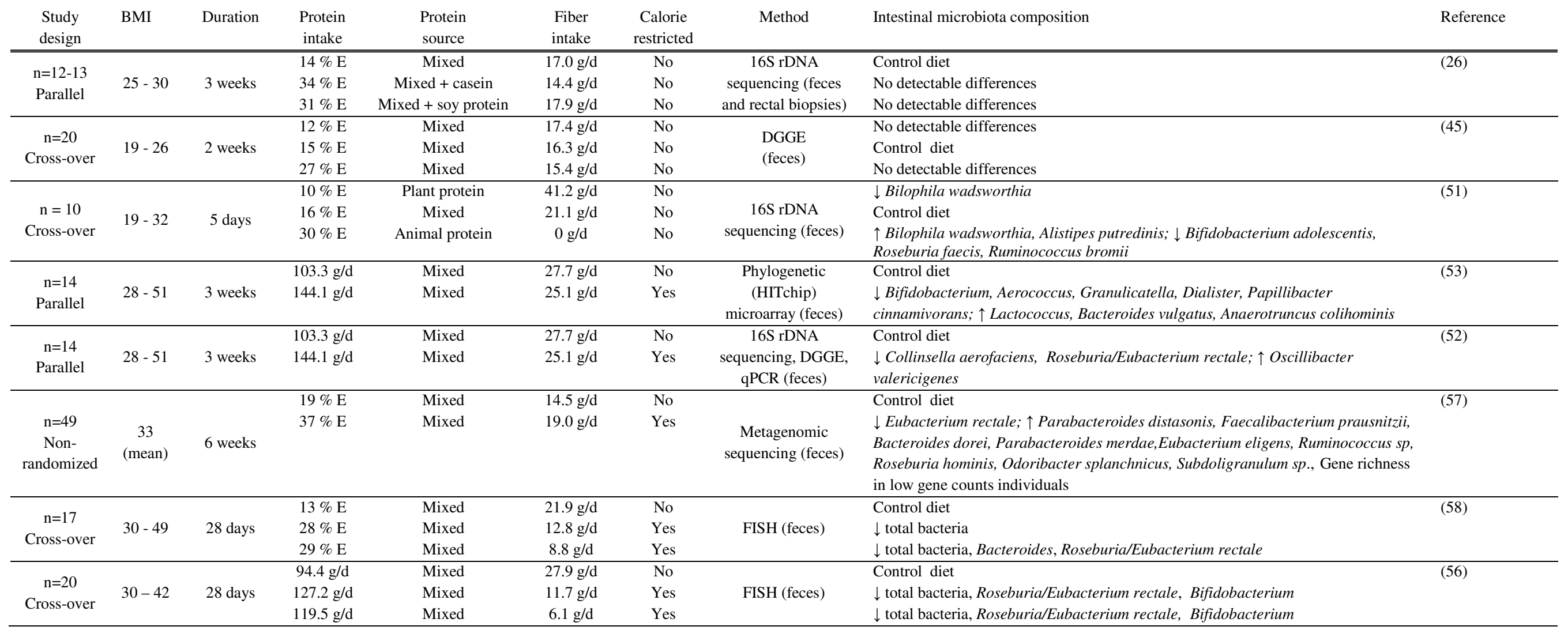


Table 2: Effects of high-protein diet on the metabolic activity of the gut microbiota. The main characteristics and findings from human intervention studies using high-protein diets are summarized. BMI: body mass index, \% E: \% of energy intake, g/d: grams/day, NMR: nuclear magnetic resonance, GC: gas chromatography, MS: mass spectrometry, LC: liquid chromatography. For carbohydrates and fat intake, the readers are referred to the original publications.

\begin{tabular}{|c|c|c|c|c|c|c|c|c|c|}
\hline $\begin{array}{l}\text { Study } \\
\text { design }\end{array}$ & BMI & Duration & $\begin{array}{l}\text { Protein } \\
\text { intake }\end{array}$ & $\begin{array}{l}\text { Protein } \\
\text { source }\end{array}$ & $\begin{array}{l}\text { Fiber } \\
\text { intake }\end{array}$ & $\begin{array}{l}\text { Calorie } \\
\text { restricted }\end{array}$ & Method & Intestinal microbiota metabolites & Reference \\
\hline \multirow{3}{*}{$\begin{array}{c}\mathrm{n}=12-13 \\
\text { Parallel }\end{array}$} & \multirow{3}{*}{$25-30$} & \multirow{3}{*}{3 weeks } & $14 \% \mathrm{E}$ & "Mixed & $17.0 \mathrm{~g} / \mathrm{d}$ & No & \multirow{3}{*}{$\begin{array}{l}\text { NMR metabolomics, } \\
\text { GC (feces) }\end{array}$} & Control diet & \multirow[t]{3}{*}{ (26) } \\
\hline & & & $34 \% \mathrm{E}$ & Mixed + casein & $14.4 \mathrm{~g} / \mathrm{d}$ & No & & $\downarrow$ butyrate; $\uparrow$ branched-chain amino acids, 2 -methylbutyrate & \\
\hline & & & $31 \% \mathrm{E}$ & Mixed + soy protein & $17.9 \mathrm{~g} / \mathrm{d}$ & No & & $\downarrow$ butyrate; $\uparrow 2$-methylbutyrate, isovalerate, valerate, phenylacetate, tyramine, & \\
\hline \multirow{2}{*}{$\begin{array}{l}n=12-13 \\
\text { Parallel }\end{array}$} & \multirow[t]{2}{*}{$25-30$} & \multirow[t]{2}{*}{3 weeks } & $34 \% \mathrm{E}$ & Mixed + casein & $14.4 \mathrm{~g} / \mathrm{d}$ & No & \multirow{2}{*}{$\begin{array}{l}\text { NMR metabolomics } \\
\text { (urines) }\end{array}$} & $\uparrow$ isobutyrate, indoxylsulfate, phenylacetylglutamine, $p$-cresylsulfate & \multirow{2}{*}{ (26) } \\
\hline & & & $31 \% \mathrm{E}$ & Mixed + soy protein & $17.9 \mathrm{~g} / \mathrm{d}$ & No & & $\uparrow$ isobutyrate, indoxylsulfate, phenylacetylglutamine & \\
\hline \multirow{2}{*}{$\begin{array}{c}\mathrm{n}=10 \\
\text { Cross-over }\end{array}$} & \multirow[b]{2}{*}{$19-32$} & \multirow[b]{2}{*}{5 days } & $10 \% \mathrm{E}$ & Plant protein & $41.2 \mathrm{~g} / \mathrm{d}$ & No & \multirow{2}{*}{$\begin{array}{c}\mathrm{GC} \\
\text { (feces) }\end{array}$} & No detectable differences & \multirow[t]{2}{*}{ (51) } \\
\hline & & & $16 \% \mathrm{E}$ & Mixed & $21.1 \mathrm{~g} / \mathrm{d}$ & No & & Control diet & \\
\hline \multirow{2}{*}{$\begin{array}{c}\mathrm{n}=14 \\
\text { Parallel }\end{array}$} & \multirow{2}{*}{$28-51$} & \multirow{2}{*}{3 weeks } & $103.3 \mathrm{~g} / \mathrm{d}$ & Mixed & $27.7 \mathrm{~g} / \mathrm{d}$ & No & \multirow{2}{*}{$\begin{array}{c}\mathrm{GC} \\
\text { (feces) }\end{array}$} & Control diet & \multirow[t]{2}{*}{ (53) } \\
\hline & & & $144.1 \mathrm{~g} / \mathrm{d}$ & Mixed & $25.1 \mathrm{~g} / \mathrm{d}$ & Yes & & $\uparrow$ isobutyrate, isovalerate, lactate; $\downarrow$ Acetate, butyrate & \\
\hline \multirow{3}{*}{$\begin{array}{c}\mathrm{n}=20 \\
\text { Cross-over }\end{array}$} & \multirow{3}{*}{$19-26$} & \multirow{3}{*}{2 weeks } & $12 \% \mathrm{E}$ & Mixed & $17.4 \mathrm{~g} / \mathrm{d}$ & No & \multirow{3}{*}{$\begin{array}{c}\text { GC-MS } \\
\text { metabolomics } \\
\text { (feces) }\end{array}$} & No detectable differences & \multirow[t]{3}{*}{ (45) } \\
\hline & & & $15 \% \mathrm{E}$ & Mixed & $16.3 \mathrm{~g} / \mathrm{d}$ & No & & Control diet & \\
\hline & & & $27 \% \mathrm{E}$ & Mixed & $15.4 \mathrm{~g} / \mathrm{d}$ & No & & $\uparrow$ isobutyrate & \\
\hline \multirow{3}{*}{$\begin{array}{c}\mathrm{n}=20 \\
\text { Cross-over }\end{array}$} & \multirow{3}{*}{$19-26$} & \multirow{3}{*}{2 weeks } & $12 \% \mathrm{E}$ & Mixed & $17.4 \mathrm{~g} / \mathrm{d}$ & No & \multirow{3}{*}{$\begin{array}{r}\text { GC-MS } \\
\text { (urine) }\end{array}$} & No detectable differences & \multirow[t]{3}{*}{ (45) } \\
\hline & & & $15 \% \mathrm{E}$ & Mixed & $16.3 \mathrm{~g} / \mathrm{d}$ & No & & Control diet & \\
\hline & & & $27 \% \mathrm{E}$ & Mixed & $15.4 \mathrm{~g} / \mathrm{d}$ & No & & $\uparrow p$-cresol & \\
\hline $\begin{array}{c}\mathrm{n}=17 \\
\text { Cross-over }\end{array}$ & $30-49$ & & $13 \% \mathrm{E}$ & Mixed & $21.9 \mathrm{~g} / \mathrm{d}$ & No & & Control diet & (58) \\
\hline & & & $94.4 \mathrm{~g} / \mathrm{d}$ & Mixed & $27.9 \mathrm{~g} / \mathrm{d}$ & No & & Control diet & (56) \\
\hline Cross-over & $30-42$ & 28 days & $127.2 \mathrm{~g} / \mathrm{d}$ & Mixed & $11.7 \mathrm{~g} / \mathrm{d}$ & Yes & $\begin{array}{c}G C \\
\text { (feces) }\end{array}$ & $\downarrow$ acetate, propionate, butyrate, valerate, lactate & \\
\hline Closs-over & & & $119.5 \mathrm{~g} / \mathrm{d}$ & Mixed & $6.1 \mathrm{~g} / \mathrm{d}$ & Yes & & $\downarrow$ acetate, propionate, butyrate, isovalerate, valerate, lactate; $\uparrow$ ammonia & \\
\hline
\end{tabular}




\section{References}

1. Hruby, A., and Hu, F. B. (2015) The Epidemiology of Obesity: A Big Picture. Pharmacoeconomics 33, 673-689

2. Thom, G., and Lean, M. (2017) Is There an Optimal Diet for Weight Management and Metabolic Health? Gastroenterology 152, 1739-1751

3. Santesso, N., Akl, E. A., Bianchi, M., Mente, A., Mustafa, R., Heels-Ansdell, D., and Schunemann, H. J. (2012) Effects of higher- versus lower-protein diets on health outcomes: a systematic review and meta-analysis. European journal of clinical nutrition 66, 780-788

4. Pesta, D. H., and Samuel, V. T. (2014) A high-protein diet for reducing body fat: mechanisms and possible caveats. Nutr Metab (Lond) 11, 53

5. Leidy, H. J., Clifton, P. M., Astrup, A., Wycherley, T. P., Westerterp-Plantenga, M. S., Luscombe-Marsh, N. D., Woods, S. C., and Mattes, R. D. (2015) The role of protein in weight loss and maintenance. Am J Clin Nutr

6. Blundell, J. E., Gibbons, C., Caudwell, P., Finlayson, G., and Hopkins, M. (2015) Appetite control and energy balance: impact of exercise. Obes Rev 16 Suppl 1, 67-76

7. Clifton, P. M., Condo, D., and Keogh, J. B. (2014) Long term weight maintenance after advice to consume low carbohydrate, higher protein diets--a systematic review and meta analysis. Nutr Metab Cardiovasc Dis 24, 224-235

8. Rueda-Clausen, C. F., Ogunleye, A. A., and Sharma, A. M. (2015) Health Benefits of Long-Term Weight-Loss Maintenance. Annual review of nutrition 35, 475-516

9. Friedman, A. N. (2004) High-protein diets: potential effects on the kidney in renal health and disease. Am J Kidney Dis 44, 950-962

10. Ko, G. J., Obi, Y., Tortorici, A. R., and Kalantar-Zadeh, K. (2017) Dietary protein intake and chronic kidney disease. Curr Opin Clin Nutr Metab Care 20, 77-85

11. Blachier, F., Beaumont, M., Andriamihaja, M., Davila, A. M., Lan, A., Grauso, M., Armand, L., Benamouzig, R., and Tome, D. (2017) Changes in the Luminal Environment of the Colonic Epithelial Cells and Physiopathological Consequences. The American journal of pathology 187, 476-486

12. Sanz, Y., Romani-Perez, M., Benitez-Paez, A., Portune, K. J., Brigidi, P., Rampelli, S., Dinan, T., Stanton, C., Delzenne, N., Blachier, F., Neyrinck, A. M., Beaumont, M., Olivares, M., Holzer, P., Gunther, K., Wolters, M., Ahrens, W., Claus, S. P., Campoy, C., Murphy, R., Sadler, C., Fernandez, L., and Kamp, J. V. (2018) Towards microbiome-informed dietary recommendations for promoting metabolic and mental health: Opinion papers of the MyNewGut project. Clin Nutr

13. Rand, W. M., Pellett, P. L., and Young, V. R. (2003) Meta-analysis of nitrogen balance studies for estimating protein requirements in healthy adults. Am J Clin Nutr 77, 109-127

14. Dubuisson, C., Lioret, S., Touvier, M., Dufour, A., Calamassi-Tran, G., Volatier, J. L., and Lafay, L. (2010) Trends in food and nutritional intakes of French adults from 1999 to 2007: results from the INCA surveys. Br J Nutr 103, 1035-1048

15. Pasiakos, S. M., Agarwal, S., Lieberman, H. R., and Fulgoni, V. L., 3rd. (2015) Sources and Amounts of Animal, Dairy, and Plant Protein Intake of US Adults in 2007-2010. Nutrients 7, 7058-7069

16. Westerterp-Plantenga, M. S., Lemmens, S. G., and Westerterp, K. R. (2012) Dietary protein its role in satiety, energetics, weight loss and health. Br J Nutr 108 Suppl 2, S105-112

17. Phillips, S. M. (2014) A brief review of higher dietary protein diets in weight loss: a focus on athletes. Sports Med $\mathbf{4 4}$ Suppl 2, S149-153

18. Tipton, K. D., and Wolfe, R. R. (2004) Protein and amino acids for athletes. J Sports Sci 22, 6579 
19. Weigle, D. S., Breen, P. A., Matthys, C. C., Callahan, H. S., Meeuws, K. E., Burden, V. R., and Purnell, J. Q. (2005) A high-protein diet induces sustained reductions in appetite, ad libitum caloric intake, and body weight despite compensatory changes in diurnal plasma leptin and ghrelin concentrations. Am J Clin Nutr 82, 41-48

20. Johnstone, A. M. (2012) Safety and efficacy of high-protein diets for weight loss. The Proceedings of the Nutrition Society 71, 339-349

21. Skov, A. R., Toubro, S., Ronn, B., Holm, L., and Astrup, A. (1999) Randomized trial on protein vs carbohydrate in ad libitum fat reduced diet for the treatment of obesity. Int J Obes Relat Metab Disord 23, 528-536

22. Claessens, M., van Baak, M. A., Monsheimer, S., and Saris, W. H. (2009) The effect of a lowfat, high-protein or high-carbohydrate ad libitum diet on weight loss maintenance and metabolic risk factors. International journal of obesity (2005) 33, 296-304

23. Aller, E. E., Larsen, T. M., Claus, H., Lindroos, A. K., Kafatos, A., Pfeiffer, A., Martinez, J. A., Handjieva-Darlenska, T., Kunesova, M., Stender, S., Saris, W. H., Astrup, A., and van Baak, M. A. (2014) Weight loss maintenance in overweight subjects on ad libitum diets with high or low protein content and glycemic index: the DIOGENES trial 12-month results. International journal of obesity (2005) 38, 1511-1517

24. Greenway, F. L. (2015) Physiological adaptations to weight loss and factors favouring weight regain. International journal of obesity (2005) 39, 1188-1196

25. Neacsu, M., Fyfe, C., Horgan, G., and Johnstone, A. M. (2014) Appetite control and biomarkers of satiety with vegetarian (soy) and meat-based high-protein diets for weight loss in obese men: a randomized crossover trial. Am J Clin Nutr 100, 548-558

26. Beaumont, M., Portune, K. J., Steuer, N., Lan, A., Cerrudo, V., Audebert, M., Dumont, F., Mancano, G., Khodorova, N., Andriamihaja, M., Airinei, G., Tome, D., Benamouzig, R., Davila, A. M., Claus, S. P., Sanz, Y., and Blachier, F. (2017) Quantity and source of dietary protein influence metabolite production by gut microbiota and rectal mucosa gene expression: a randomized, parallel, double-blind trial in overweight humans. Am J Clin Nutr 106, 1005-1019

27. Theodorakopoulos, C., Jones, J., Bannerman, E., and Greig, C. A. (2017) Effectiveness of nutritional and exercise interventions to improve body composition and muscle strength or function in sarcopenic obese older adults: A systematic review. Nutr Res 43, 3-15

28. Dattilo, A. M., and Kris-Etherton, P. M. (1992) Effects of weight reduction on blood lipids and lipoproteins: a meta-analysis. Am J Clin Nutr 56, 320-328

29. Silvester, K. R., and Cummings, J. H. (1995) Does digestibility of meat protein help explain large bowel cancer risk? Nutr Cancer 24, 279-288

30. Bos, C., Juillet, B., Fouillet, H., Turlan, L., Dare, S., Luengo, C., N'Tounda, R., Benamouzig, R., Gausseres, N., Tome, D., and Gaudichon, C. (2005) Postprandial metabolic utilization of wheat protein in humans. Am J Clin Nutr 81, 87-94

31. Tome, D. (2012) Criteria and markers for protein quality assessment - a review. Br J Nutr 108 Suppl 2, S222-229

32. Bos, C., Airinei, G., Mariotti, F., Benamouzig, R., Berot, S., Evrard, J., Fenart, E., Tome, D., and Gaudichon, C. (2007) The poor digestibility of rapeseed protein is balanced by its very high metabolic utilization in humans. J Nutr 137, 594-600

33. Evenepoel, P., Claus, D., Geypens, B., Hiele, M., Geboes, K., Rutgeerts, P., and Ghoos, Y. (1999) Amount and fate of egg protein escaping assimilation in the small intestine of humans. Am J Physiol 277, G935-943

34. Oberli, M., Marsset-Baglieri, A., Airinei, G., Sante-Lhoutellier, V., Khodorova, N., Remond, D., Foucault-Simonin, A., Piedcoq, J., Tome, D., Fromentin, G., Benamouzig, R., and Gaudichon, C. (2015) High True lleal Digestibility but Not Postprandial Utilization of Nitrogen from Bovine Meat Protein in Humans Is Moderately Decreased by High-Temperature, Long-Duration Cooking. J Nutr 145, 2221-2228

35. Chacko, A., and Cummings, J. H. (1988) Nitrogen losses from the human small bowel: obligatory losses and the effect of physical form of food. Gut 29, 809-815 
36. Gaudichon, C., Bos, C., Morens, C., Petzke, K. J., Mariotti, F., Everwand, J., Benamouzig, R., Dare, S., Tome, D., and Metges, C. C. (2002) lleal losses of nitrogen and amino acids in humans and their importance to the assessment of amino acid requirements. Gastroenterology 123, 50-59

37. Gibson, J. A., Sladen, G. E., and Dawson, A. M. (1976) Protein absorption and ammonia production: the effects of dietary protein and removal of the colon. Br J Nutr 35, 61-65

38. Bax, M. L., Buffiere, C., Hafnaoui, N., Gaudichon, C., Savary-Auzeloux, I., Dardevet, D., SanteLhoutellier, V., and Remond, D. (2013) Effects of meat cooking, and of ingested amount, on protein digestion speed and entry of residual proteins into the colon: a study in minipigs. PloS one 8, e61252

39. Schippa, S., and Conte, M. P. (2014) Dysbiotic events in gut microbiota: impact on human health. Nutrients 6, 5786-5805

40. Dinning, P. G. (2016) Recording In Vivo Human Colonic Motility: What Have We Learnt Over the Past 100 Years? Advances in experimental medicine and biology 891, 213-222

41. Portune K J, B. M., Davila AM, Tome D, Blachier F, Sanz Y. (2016) Gut microbiota role in dietary protein metabolism and health-related outcomes: The two sides of the coin. Trends in Food Science and Technology 57, 213-232

42. Fuller, M. (2012) Determination of protein and amino acid digestibility in foods including implications of gut microbial amino acid synthesis. Br J Nutr 108 Suppl 2, S238-246

43. van der Wielen, N., Moughan, P. J., and Mensink, M. (2017) Amino Acid Absorption in the Large Intestine of Humans and Porcine Models. J Nutr 147, 1493-1498

44. Davila, A. M., Blachier, F., Gotteland, M., Andriamihaja, M., Benetti, P. H., Sanz, Y., and Tome, D. (2013) Intestinal luminal nitrogen metabolism: Role of the gut microbiota and consequences for the host. Pharmacological research : the official journal of the Italian Pharmacological Society 68, 95-107

45. Windey, K., De Preter, V., Louat, T., Schuit, F., Herman, J., Vansant, G., and Verbeke, K. (2012) Modulation of protein fermentation does not affect fecal water toxicity: a randomized crossover study in healthy subjects. PloS one 7, e52387

46. Mottawea, W., Chiang, C. K., Muhlbauer, M., Starr, A. E., Butcher, J., Abujamel, T., Deeke, S. A., Brandel, A., Zhou, H., Shokralla, S., Hajibabaei, M., Singleton, R., Benchimol, E. I., Jobin, C., Mack, D. R., Figeys, D., and Stintzi, A. (2016) Altered intestinal microbiota-host mitochondria crosstalk in new onset Crohn's disease. Nat Commun 7, 13419

47. Nyangale, E. P., Mottram, D. S., and Gibson, G. R. (2012) Gut microbial activity, implications for health and disease: the potential role of metabolite analysis. Journal of proteome research 11, 5573-5585

48. Sharon, G., Garg, N., Debelius, J., Knight, R., Dorrestein, P. C., and Mazmanian, S. K. (2014) Specialized metabolites from the microbiome in health and disease. Cell metabolism 20, 719730

49. Louis, P., Hold, G. L., and Flint, H. J. (2014) The gut microbiota, bacterial metabolites and colorectal cancer. Nature reviews. Microbiology 12, 661-672

50. Boleij, A., and Tjalsma, H. (2012) Gut bacteria in health and disease: a survey on the interface between intestinal microbiology and colorectal cancer. Biol Rev Camb Philos Soc 87, 701-730

51. David, L. A., Maurice, C. F., Carmody, R. N., Gootenberg, D. B., Button, J. E., Wolfe, B. E., Ling, A. V., Devlin, A. S., Varma, Y., Fischbach, M. A., Biddinger, S. B., Dutton, R. J., and Turnbaugh, P. J. (2014) Diet rapidly and reproducibly alters the human gut microbiome. Nature 505, 559563

52. Walker, A. W., Ince, J., Duncan, S. H., Webster, L. M., Holtrop, G., Ze, X., Brown, D., Stares, M. D., Scott, P., Bergerat, A., Louis, P., McIntosh, F., Johnstone, A. M., Lobley, G. E., Parkhill, J., and Flint, H. J. (2011) Dominant and diet-responsive groups of bacteria within the human colonic microbiota. The ISME journal 5, 220-230

53. Salonen, A., Lahti, L., Salojarvi, J., Holtrop, G., Korpela, K., Duncan, S. H., Date, P., Farquharson, F., Johnstone, A. M., Lobley, G. E., Louis, P., Flint, H. J., and de Vos, W. M. 
(2014) Impact of diet and individual variation on intestinal microbiota composition and fermentation products in obese men. The ISME journal 8, 2218-2230

54. Martinez-Garcia, M., Diaz-Valdes, M., and Anton, J. (2010) Diversity of pufM genes, involved in aerobic anoxygenic photosynthesis, in the bacterial communities associated with colonial ascidians. FEMS Microbiol Ecol 71, 387-398

55. Martinez, I., Kim, J., Duffy, P. R., Schlegel, V. L., and Walter, J. (2010) Resistant starches types 2 and 4 have differential effects on the composition of the fecal microbiota in human subjects. PloS one 5, e15046

56. Duncan, S. H., Belenguer, A., Holtrop, G., Johnstone, A. M., Flint, H. J., and Lobley, G. E. (2007) Reduced dietary intake of carbohydrates by obese subjects results in decreased concentrations of butyrate and butyrate-producing bacteria in feces. Appl Environ Microbiol 73, 1073-1078

57. Cotillard, A., Kennedy, S. P., Kong, L. C., Prifti, E., Pons, N., Le Chatelier, E., Almeida, M., Quinquis, B., Levenez, F., Galleron, N., Gougis, S., Rizkalla, S., Batto, J. M., Renault, P., consortium, A. N. R. M., Dore, J., Zucker, J. D., Clement, K., Ehrlich, S. D., Blottiere, H., Leclerc, M., Juste, C., de Wouters, T., Lepage, P., Fouqueray, C., Basdevant, A., Henegar, C., Godard, C., Fondacci, M., Rohia, A., Hajduch, F., Weissenbach, J., Pelletier, E., Le Paslier, D., Gauchi, J. P., Gibrat, J. F., Loux, V., Carre, W., Maguin, E., van de Guchte, M., Jamet, A., Boumezbeur, F., and Layec, S. (2013) Dietary intervention impact on gut microbial gene richness. Nature 500, 585-588

58. Russell, W. R., Gratz, S. W., Duncan, S. H., Holtrop, G., Ince, J., Scobbie, L., Duncan, G., Johnstone, A. M., Lobley, G. E., Wallace, R. J., Duthie, G. G., and Flint, H. J. (2011) Highprotein, reduced-carbohydrate weight-loss diets promote metabolite profiles likely to be detrimental to colonic health. Am J Clin Nutr 93, 1062-1072

59. Geypens, B., Claus, D., Evenepoel, P., Hiele, M., Maes, B., Peeters, M., Rutgeerts, P., and Ghoos, Y. (1997) Influence of dietary protein supplements on the formation of bacterial metabolites in the colon. Gut 41, 70-76

60. Wikoff, W. R., Anfora, A. T., Liu, J., Schultz, P. G., Lesley, S. A., Peters, E. C., and Siuzdak, G. (2009) Metabolomics analysis reveals large effects of gut microflora on mammalian blood metabolites. Proc Natl Acad Sci U S A 106, 3698-3703

61. Roager, H. M., Hansen, L. B., Bahl, M. I., Frandsen, H. L., Carvalho, V., Gobel, R. J., Dalgaard, M. D., Plichta, D. R., Sparholt, M. H., Vestergaard, H., Hansen, T., Sicheritz-Ponten, T., Nielsen, H. B., Pedersen, O., Lauritzen, L., Kristensen, M., Gupta, R., and Licht, T. R. (2016) Colonic transit time is related to bacterial metabolism and mucosal turnover in the gut. Nat Microbiol 1, 16093

62. Nugent, S. G., Kumar, D., Rampton, D. S., and Evans, D. F. (2001) Intestinal luminal pH in inflammatory bowel disease: possible determinants and implications for therapy with aminosalicylates and other drugs. Gut 48, 571-577

63. Blachier, F., Davila, A. M., Mimoun, S., Benetti, P. H., Atanasiu, C., Andriamihaja, M., Benamouzig, R., Bouillaud, F., and Tome, D. (2010) Luminal sulfide and large intestine mucosa: friend or foe? Amino Acids 39, 335-347

64. Cummings, J. H., Hill, M. J., Bone, E. S., Branch, W. J., and Jenkins, D. J. (1979) The effect of meat protein and dietary fiber on colonic function and metabolism. II. Bacterial metabolites in feces and urine. Am J Clin Nutr 32, 2094-2101

65. Lozupone, C. A., Stombaugh, J. I., Gordon, J. I., Jansson, J. K., and Knight, R. (2012) Diversity, stability and resilience of the human gut microbiota. Nature 489, 220-230

66. Hamer, H. M., Jonkers, D., Venema, K., Vanhoutvin, S., Troost, F. J., and Brummer, R. J. (2008) Review article: the role of butyrate on colonic function. Alimentary pharmacology \& therapeutics 27, 104-119

67. Thibault, R., Blachier, F., Darcy-Vrillon, B., de Coppet, P., Bourreille, A., and Segain, J. P. (2010) Butyrate utilization by the colonic mucosa in inflammatory bowel diseases: a transport deficiency. Inflamm Bowel Dis 16, 684-695 
68. Magee, E. A., Richardson, C. J., Hughes, R., and Cummings, J. H. (2000) Contribution of dietary protein to sulfide production in the large intestine: an in vitro and a controlled feeding study in humans. Am J Clin Nutr 72, 1488-1494

69. Mimoun, S., Andriamihaja, M., Chaumontet, C., Atanasiu, C., Benamouzig, R., Blouin, J. M., Tome, D., Bouillaud, F., and Blachier, F. (2012) Detoxification of H(2)S by differentiated colonic epithelial cells: implication of the sulfide oxidizing unit and of the cell respiratory capacity. Antioxid Redox Signal 17, 1-10

70. Andriamihaja, M., Lan, A., Beaumont, M., Audebert, M., Wong, X., Yamada, K., Yin, Y., Tome, D., Carrasco-Pozo, C., Gotteland, M., Kong, X., and Blachier, F. (2015) The deleterious metabolic and genotoxic effects of the bacterial metabolite $p$-cresol on colonic epithelial cells. Free Radic Biol Med 85, 219-227

71. Dodd, D., Spitzer, M. H., Van Treuren, W., Merrill, B. D., Hryckowian, A. J., Higginbottom, S. K., Le, A., Cowan, T. M., Nolan, G. P., Fischbach, M. A., and Sonnenburg, J. L. (2017) A gut bacterial pathway metabolizes aromatic amino acids into nine circulating metabolites. Nature 551, 648-652

72. Pearson, J. R., Gill, C. I., and Rowland, I. R. (2009) Diet, fecal water, and colon cancer-development of a biomarker. Nutrition reviews 67, 509-526

73. Benassi-Evans, B., Clifton, P., Noakes, M., and Fenech, M. (2010) High-protein/high red meat and high-carbohydrate weight-loss diets do not differ in their effect on faecal water genotoxicity tested by use of the WIL2-NS cell line and with other biomarkers of bowel health. Mutation research 703, 130-136

74. Pedersen, G., Brynskov, J., and Saermark, T. (2002) Phenol toxicity and conjugation in human colonic epithelial cells. Scand J Gastroenterol 37, 74-79

75. Ramakrishna, B. S., Roberts-Thomson, I. C., Pannall, P. R., and Roediger, W. E. (1991) Impaired sulphation of phenol by the colonic mucosa in quiescent and active ulcerative colitis. Gut 32, 46-49

76. Gryp, T., Vanholder, R., Vaneechoutte, M., and Glorieux, G. (2017) p-Cresyl Sulfate. Toxins (Basel) 9

77. Windey, K., De Preter, V., and Verbeke, K. (2012) Relevance of protein fermentation to gut health. Mol Nutr Food Res 56, 184-196

78. Poveda, J., Sanchez-Nino, M. D., Glorieux, G., Sanz, A. B., Egido, J., Vanholder, R., and Ortiz, A. (2014) p-cresyl sulphate has pro-inflammatory and cytotoxic actions on human proximal tubular epithelial cells. Nephrol Dial Transplant 29, 56-64

79. Watanabe, H., Miyamoto, Y., Honda, D., Tanaka, H., Wu, Q., Endo, M., Noguchi, T., Kadowaki, D., Ishima, Y., Kotani, S., Nakajima, M., Kataoka, K., Kim-Mitsuyama, S., Tanaka, M., Fukagawa, M., Otagiri, M., and Maruyama, T. (2013) p-Cresyl sulfate causes renal tubular cell damage by inducing oxidative stress by activation of NADPH oxidase. Kidney international $\mathbf{8 3}$, 582-592

80. Wu, G. D., Chen, J., Hoffmann, C., Bittinger, K., Chen, Y. Y., Keilbaugh, S. A., Bewtra, M., Knights, D., Walters, W. A., Knight, R., Sinha, R., Gilroy, E., Gupta, K., Baldassano, R., Nessel, L., Li, H., Bushman, F. D., and Lewis, J. D. (2011) Linking long-term dietary patterns with gut microbial enterotypes. Science 334, 105-108

81. Lin, C. J., Pan, C. F., Chuang, C. K., Sun, F. J., Wang, D. J., Chen, H. H., Liu, H. L., and Wu, C. J. (2014) P-cresyl sulfate is a valuable predictor of clinical outcomes in pre-ESRD patients. Biomed Res Int 2014, 526932

82. Bansal, T., Alaniz, R. C., Wood, T. K., and Jayaraman, A. (2010) The bacterial signal indole increases epithelial-cell tight-junction resistance and attenuates indicators of inflammation. Proc Natl Acad Sci U S A 107, 228-233

83. Shimada, Y., Kinoshita, M., Harada, K., Mizutani, M., Masahata, K., Kayama, H., and Takeda, K. (2013) Commensal bacteria-dependent indole production enhances epithelial barrier function in the colon. PloS one 8, e80604 
84. Beaumont, M., Neyrinck, A. M., Olivares, M., Rodriguez, J., de Rocca Serra, A., Roumain, M., Bindels, L. B., Cani, P. D., Evenepoel, P., Muccioli, G. G., Demoulin, J. B., and Delzenne, N. M. (2018) The gut microbiota metabolite indole alleviates liver inflammation in mice. FASEB journal : official publication of the Federation of American Societies for Experimental Biology, fj201800544

85. Hubbard, T. D., Murray, I. A., Bisson, W. H., Lahoti, T. S., Gowda, K., Amin, S. G., Patterson, A. D., and Perdew, G. H. (2015) Adaptation of the human aryl hydrocarbon receptor to sense microbiota-derived indoles. Sci Rep 5, 12689

86. Cheng, Y., Jin, U. H., Allred, C. D., Jayaraman, A., Chapkin, R. S., and Safe, S. (2015) Aryl Hydrocarbon Receptor Activity of Tryptophan Metabolites in Young Adult Mouse Colonocytes. Drug Metab Dispos 43, 1536-1543

87. Santes-Palacios, R., Ornelas-Ayala, D., Cabanas, N., Marroquin-Perez, A., Hernandez-Magana, A., Del Rosario Olguin-Reyes, S., Camacho-Carranza, R., and Espinosa-Aguirre, J. J. (2016) Regulation of Human Cytochrome P4501A1 (hCYP1A1): A Plausible Target for Chemoprevention? Biomed Res Int 2016, 5341081

88. He, X., and Feng, S. (2015) Role of Metabolic Enzymes P450 (CYP) on Activating Procarcinogen and their Polymorphisms on the Risk of Cancers. Curr Drug Metab 16, 850-863

89. Badal, S., and Delgoda, R. (2014) Role of the modulation of CYP1A1 expression and activity in chemoprevention. J Appl Toxicol 34, 743-753

90. Leong, S. C., and Sirich, T. L. (2016) Indoxyl Sulfate-Review of Toxicity and Therapeutic Strategies. Toxins (Basel) 8

91. Tan, X., Cao, X., Zou, J., Shen, B., Zhang, X., Liu, Z., Lv, W., Teng, J., and Ding, X. (2017) Indoxyl sulfate, a valuable biomarker in chronic kidney disease and dialysis. Hemodial Int 21, 161-167

92. Ramezani, A., and Raj, D. S. (2014) The gut microbiome, kidney disease, and targeted interventions. Journal of the American Society of Nephrology : JASN 25, 657-670

93. Spooren, C. E., Pierik, M. J., Zeegers, M. P., Feskens, E. J., Masclee, A. A., and Jonkers, D. M. (2013) Review article: the association of diet with onset and relapse in patients with inflammatory bowel disease. Alimentary pharmacology \& therapeutics 38, 1172-1187

94. Jantchou, P., Morois, S., Clavel-Chapelon, F., Boutron-Ruault, M. C., and Carbonnel, F. (2010) Animal protein intake and risk of inflammatory bowel disease: The E3N prospective study. The American journal of gastroenterology 105, 2195-2201

95. Jowett, S. L., Seal, C. J., Pearce, M. S., Phillips, E., Gregory, W., Barton, J. R., and Welfare, M. R. (2004) Influence of dietary factors on the clinical course of ulcerative colitis: a prospective cohort study. Gut 53, 1479-1484

96. Arijs, I., Vanhove, W., Rutgeerts, P., Schuit, F., Verbeke, K., and De Preter, V. (2013) Decreased mucosal sulfide detoxification capacity in patients with Crohn's disease. Inflamm Bowel Dis 19, E70-72

97. De Preter, V., Arijs, I., Windey, K., Vanhove, W., Vermeire, S., Schuit, F., Rutgeerts, P., and Verbeke, K. (2012) Decreased mucosal sulfide detoxification is related to an impaired butyrate oxidation in ulcerative colitis. Inflamm Bowel Dis 18, 2371-2380

98. Beaumont, M., Andriamihaja, M., Lan, A., Khodorova, N., Audebert, M., Blouin, J. M., Grauso, M., Lancha, L., Benetti, P. H., Benamouzig, R., Tome, D., Bouillaud, F., Davila, A. M., and Blachier, F. (2016) Detrimental effects for colonocytes of an increased exposure to luminal hydrogen sulfide: The adaptive response. Free Radic Biol Med 93, 155-164

99. Mu, C., Yang, Y., Luo, Z., Guan, L., and Zhu, W. (2016) The Colonic Microbiome and Epithelial Transcriptome Are Altered in Rats Fed a High-Protein Diet Compared with a Normal-Protein Diet. J Nutr 146, 474-483

100. Beaumont, M., Andriamihaja, M., Armand, L., Grauso, M., Jaffrezic, F., Laloe, D., Moroldo, M., Davila, A. M., Tome, D., Blachier, F., and Lan, A. (2017) Epithelial response to a high-protein diet in rat colon. BMC Genomics 18, 116 
101. Vanholder, R., Schepers, E., Pletinck, A., Nagler, E. V., and Glorieux, G. (2014) The uremic toxicity of indoxyl sulfate and p-cresyl sulfate: a systematic review. Journal of the American Society of Nephrology : JASN 25, 1897-1907

102. Chimerel, C., Emery, E., Summers, D. K., Keyser, U., Gribble, F. M., and Reimann, F. (2014) Bacterial metabolite indole modulates incretin secretion from intestinal enteroendocrine $L$ cells. Cell Rep 9, 1202-1208

103. Tomasova, L., Dobrowolski, L., Jurkowska, H., Wrobel, M., Huc, T., Ondrias, K., Ostaszewski, R., and Ufnal, M. (2016) Intracolonic hydrogen sulfide lowers blood pressure in rats. Nitric Oxide 60, 50-58

104. Pichette, J., Fynn-Sackey, N., and Gagnon, J. (2017) Hydrogen Sulfide and Sulfate Prebiotic Stimulates the Secretion of GLP-1 and Improves Glycemia in Male Mice. Endocrinology 158, 3416-3425 


\section{Figure 1}

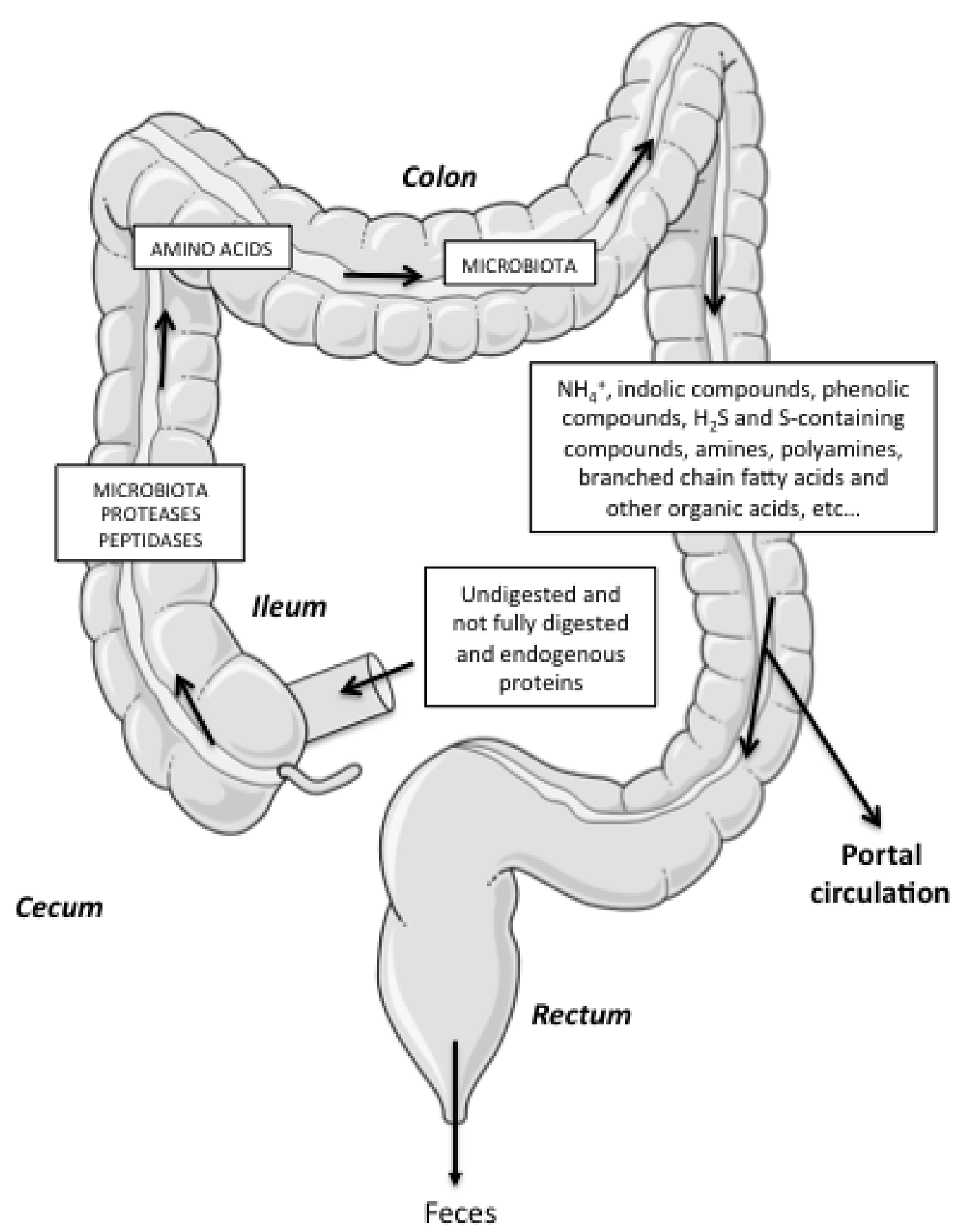




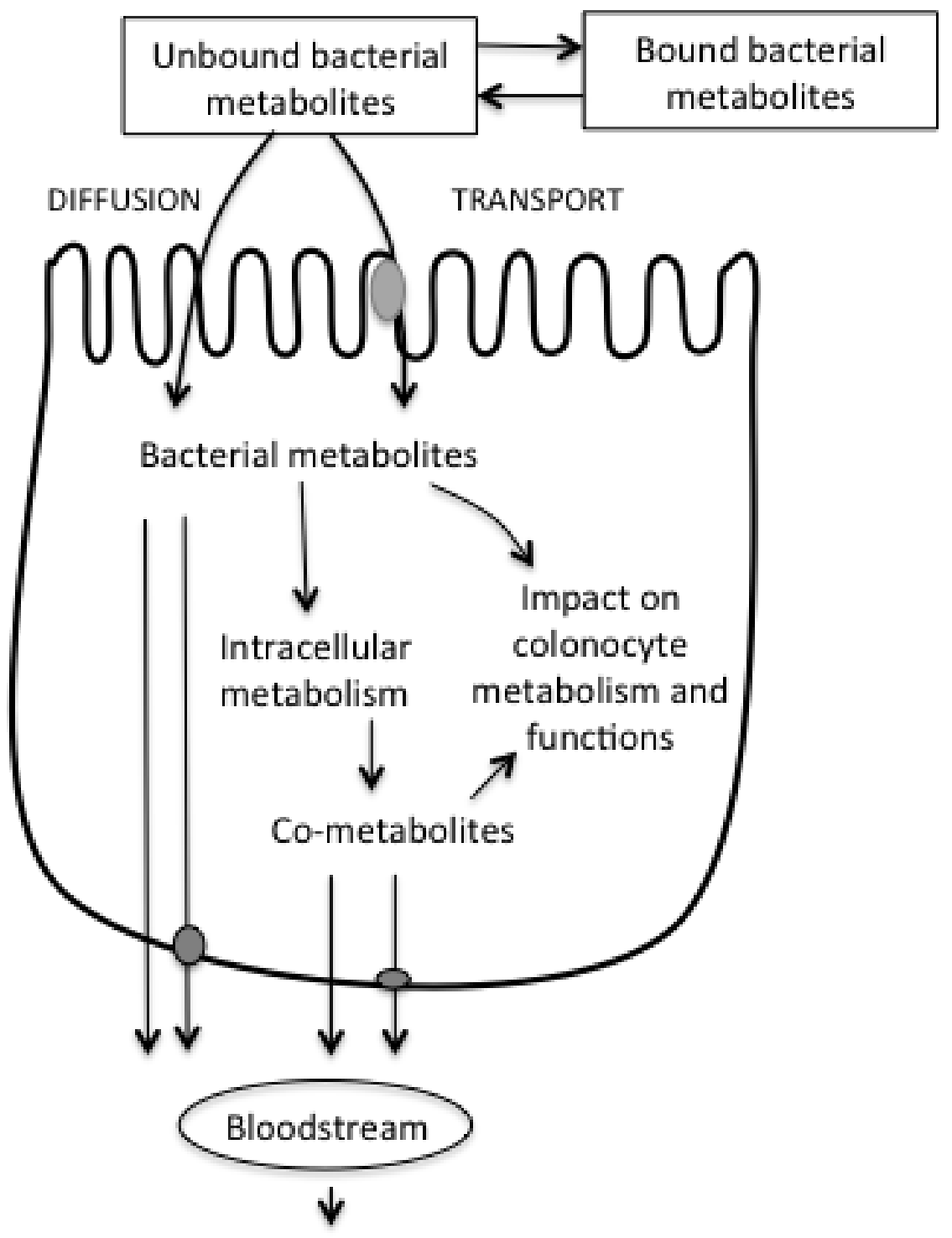

Liver and peripheric organs

$\downarrow$
Kidney $\rightarrow \quad \begin{gathered}\text { Accumulation } \\ \text { in urine }\end{gathered}$ 


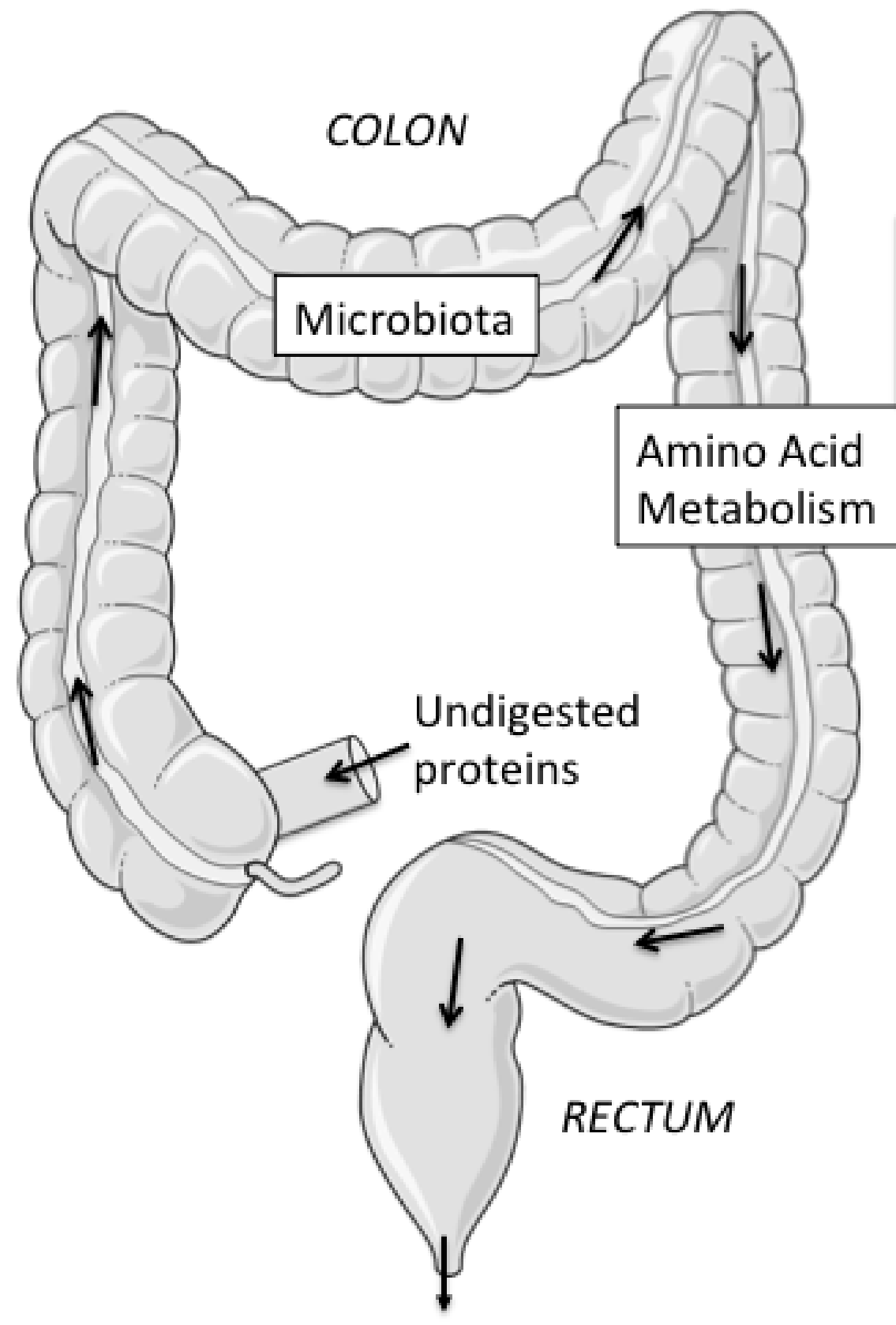

Amino-acid derived bacterial metabolites

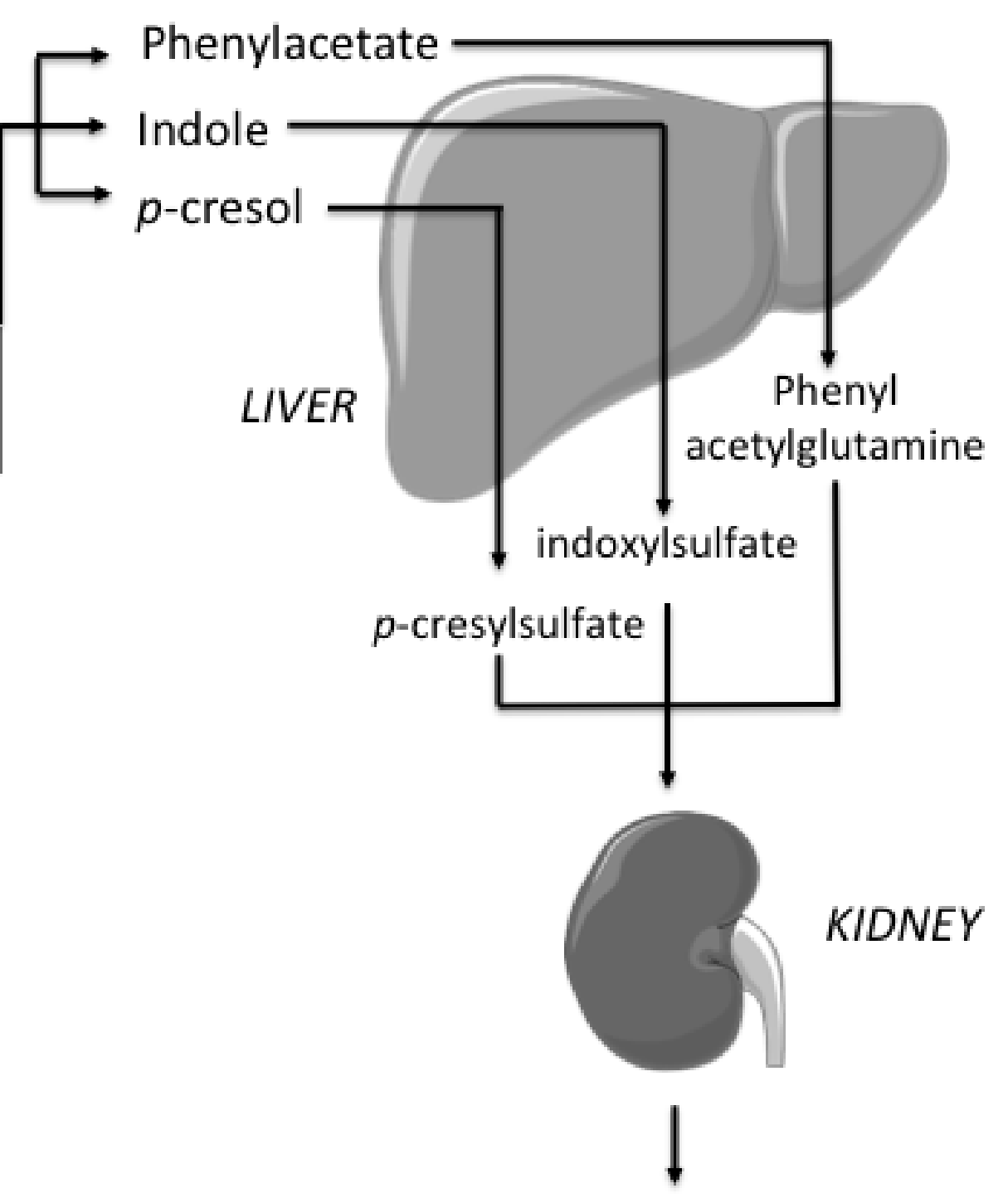

Amino-acid derived bacterial metabolites and co-metabolites 